\title{
Clonal variation in a Florida Bay Thalassia testudinum meadow: molecular genetic assessment of population structure
}

\author{
Jenny L. Davis ${ }^{1,2}$, Daniel L. Childers ${ }^{1,2, *}$, David N. Kuhn ${ }^{1}$ \\ ${ }^{1}$ Department of Biological Sciences and ${ }^{2}$ Southeast Environmental Research Program (SERP), Florida International University, \\ University Park, Miami, Florida 33199, USA
}

\begin{abstract}
Thalassia testudinum (Banks ex König) is an important primary producer in nearshore tropical marine ecosystems. In the past several years, mass mortality of $T$ testudinum populations within the Florida Bay estuary has highlighted the need to know more about levels of clonal variation and the spatial arrangement of genets within populations of this species. Historically, most of the reproduction within this species was thought to be through clonal growth, and populations have been assumed to exhibit little genetic diversity. We used DNA fingerprinting techniques and spatially hierarchical sampling to search for genetically distinct plants within $T$. testudinum meadows in Rabbit Key Basin, Florida Bay, USA. We detected 22 genetically distinct individuals out of 74 samples. Multiple genetic individuals were detected over small spatial scales $(<0.25 \mathrm{~m})$. Analysis of molecular variance (AMOVA) detected significant levels of variation at both the largest and smallest spatial scales studied. This result suggested that genets of this species generally do not grow in discreet monoclonal patches and that most genets are not large enough to span the entire basin $(\sim 5 \mathrm{~km})$. Further, analysis of genetic distances between phenotypes suggests a pattern of isolation by distance, with individuals that were nearer in space being more genetically similar. GIS analysis of seagrass density over the period from 1985 to 1994 , combined with the clonal diversity data presented here, suggest seedlings may play a significant role in colonization of bare patches. These results imply that the role of sexual reproduction in population structure within this species is greater than previously thought.
\end{abstract}

KEY WORDS: Seagrass . Thalassia testudinum - Genetic variation · Population structure - Interrepeat SSR

\section{INTRODUCTION}

Thalassia testudinum Banks ex König is the dominant seagrass species in nearshore waters of the Gulf of Mexico and Caribbean (Den Hartog 1970). Like other seagrasses, this species plays a major role in the structure and function of the ecosystems it inhabits through creating 3-dimensional habitat, stabilizing sediments, and providing surface area for epiphyte growth (Leber 1985, Stoner \& Lewis 1985, Lewis 1987 , Kaehler \& Hughes 1992, Hall \& Bell 1993, Frankovich \& Zieman 1994, Murphey \& Fonseca 1995, Koch 1996). The importance of $T$. testudinum and other seagrass

\footnotetext{
-Addressee for correspondence. E-mail: childers@fiu.edu
}

species to the systems which they dominate is generally agreed upon, yet we still have little understanding of the population structure and dynamics of this important primary producer.

The extent of Thalassia testudinum within the Florida Bay estuary is testimony to its importance: it has been estimated to make up $90 \%$ of the macrophyte standing crop within this system (Iverson \& Bittaker 1986, Zieman et al. 1989). In the past 10 yr, large scale die-offs have been observed in $T$. testudinum populations within Florida Bay (Robblee et al. 1991). While multiple potential causes of the die-offs have been investigated, no single explanation for these events has been determined. This has led many researchers to speculate that several environmental stresses working synergistically are responsible for die-off (Carlson et 
al. 1994, Durako \& Kuss 1994, Tomasko \& LaPointe 1994, Zieman et al. 1994). It has been further postulated that low genetic diversity within $T$. testudinum populations may have played a role in die-off by rendering $T$. testudinum populations less resistant to disturbance (Schlueter \& Guttman 1998). The search for a cause for $T$. testudinum die-off in Florida Bay has thus highlighted the need to know more about how natural seagrass populations are structured.

Seagrasses in general are characterized by vegetative or clonal growth (Barrett et al. 1993, Grace 1993, Laushman 1993). In Thalassia testudinum, clonal growth occurs through extension and branching of a horizontal rhizome (Tomlinson 1974). Through this type of growth, it is conceivable that individual plants may cover very large areas. Identification of genetic individuals is complicated by the dense matrix of interconnected, underground horizontal rhizomes (Cook 1983). Thus, the clonal growth form has obscured our understanding of seagrass population dynamics.

Thalassia testudinum is a dioecious monocot, capable of both vegetative and sexual reproduction. The predominance of sexual reproduction varies both spatially and temporally and is reportedly sporadic in some locations (Tomlinson 1969, Williams \& Adey 1983, Durako \& Moffler 1985, 1987, van Tussenbroek 1994. Witz \& Dawes 1995). Pollination within this species is completely hydrophilous (Tomlinson 1969, Cox 1993). Pollen grains are covered with a sticky, mucilaginous film, and are released from flowers at the sediment surface, making it unlikely that pollen travels far (Tomlinson 1969, Cox \& Tomlinson 1988, Cox 1993). At maturity, the fruits may be broken away from the plant and carried off by currents, or may open while still attached to the plant, releasing the seeds which generally sink immediately but in some may cases may float for several hours before sinking back to the sediment (Orpurt \& Boral 1964, Sculthorpe 1967). Because the seeds may be buoyant, it has been suggested that they are primarily agents of dispersal and play only a small role in local population structure (van Tussenbroek 1994). Additionally, measured seedling success rates are low, and this further confounds the importance of sexual reproduction to local population structure (Williams \& Adey 1983).

Early studies of population genetics in seagrasses using enzyme techniques reported a general lack of diversity within the seagrass species (McMillan 1980 , 1982). Later, more thorough studies using allozyme analysis uncovered higher than previously expected levels of variation within populations of Posidonia australis (Waycott et al. 1997), Posidonia oceanica (Capiomont et al. 1996) and Zostera marina (Harrison \& Durance 1992, Ruckelshaus 1996). More recently, allozymes have been used to detect variation within Tha- lassia testudinum populations in the lower Florida Keys (Schlueter \& Guttman 1998).

While allozymes are excellent markers for some questions, molecular markers are much more variable and, thus, better for detecting differences between closely related individuals (Haymes 1994, Parker et al. 1998). Recent advances in DNA technology have made it easier to look at diversity at the molecular level. DNA fingerprinting techniques such as restriction fragment length polymorphisms (RFLP) and randomly amplified polymorphic DNAs (RAPDs) have been used to examine levels of clonal variation in several seagrass species (Alberte et al. 1994, Waycott 1995, Procaccini \& Mazzella 1996, Waycott et al. 1996, Kirsten et al. 1998). In these studies, the molecular data have uncovered large numbers of clones. In only 1 case to date do the molecular data not suggest higher than expected levels of diversity (Waycott et al. 1996). The ease of using DNA fingerprinting techniques combined with their high information content makes these tools invaluable in discerning population structure of clonal plants. In this study, we used DNA fingerprinting techniques to investigate the degree of clonal diversity in the seagrass Thalassia testudinum within Florida Bay. We investigated; (1) whether or not DNA fingerprinting could detect any clonal variability within these populations; and (2) the spatial scales at which this variability occurred. Additionally, we used die-off and recolonization maps generated from high-resolution satellite imagery to search for temporal trends in clonal diversity and to address the possibility of a link between clonal diversity and seagrass die-off.

\section{METHODS}

Study area. Samples were collected from within Rabbit Key Basin in the western region of Florida Bay, USA (Fig. 1). Rabbit Key Basin is a relatively large basin (approx. $25 \mathrm{~km}^{2}$ ) with an average depth of $1.5 \mathrm{~m}$ that is surrounded by shallow carbonate mudbanks. We chose Rabbit Key Basin for this study because Thalassia testudinum die-off events have been well documented in this basin (Robblee et al. 1991).

Sample collection. We utilized a probability based random sampling design similar to that of the Environmental Protection Agency's Environmental Monitoring and Assessment Program (EMAP); (Stevens 1994, S. Liebowicz, EPA. pers. comm.) We overlaid a chart of Rabbit Key Basin with a hexagonal sampling grid designed such that 10 hexagons covered essentially the entire area of the basin (Fig. 2). One sampling point was identified in each of the 10 hexagons by randomly selecting longitude and latitude coordinates. This type of design was chosen to avoid the potential for spatial 


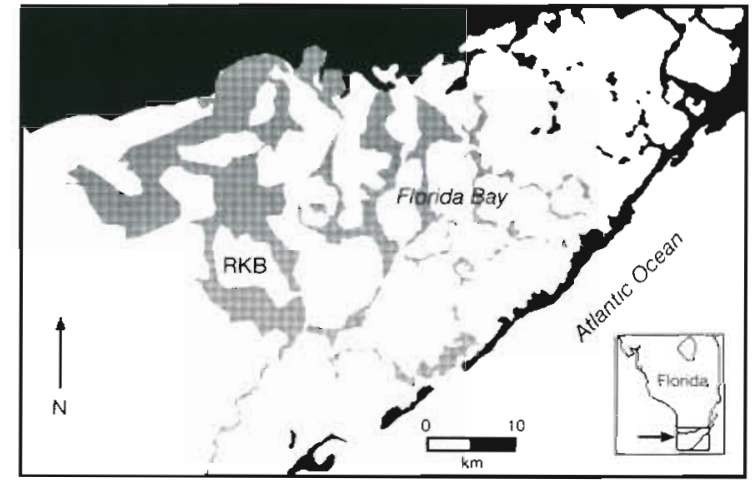

Fig. 1. Florida Bay. Grey areas represent shallow mudbank. All samples analyzed in this study were collected from within Rabbit Key Basin (RKB)

clustering that is inherent in randomly assigned site locations.

After locating each sampling site with GPS, we quantified Thalassia testudinum short shoot density by randomly placing ten $0.0625 \mathrm{~m}^{2}$ quadrats in the vicinity of the sampling point and counting all short shoots within each quadrat. The 10 measurements were averaged to generate a mean density value for each location. To collect tissue for genetic analysis, two $0.0625 \mathrm{~m}^{2}$ quadrats were thrown haphazardly from the randomly selected point. The distance between the 2 quadrats was measured. Straight-edged shovels were then used to remove the sediment plug from within each quadrat. The plugs were rinsed to remove sediment from the root/rhizome matrix and the individual rhizomes were carefully teased apart. From each plug we collected 5 rhizomes that were not connected to each other within the area of the plug, and harvested their attached short shoots for genetic analysis. The 100 (10 hexagons $\times 2$ quadrats $\times 5$ rhizomes) total rhizomes that were collected in this manner are hereafter referred to as 'potential individuals'.

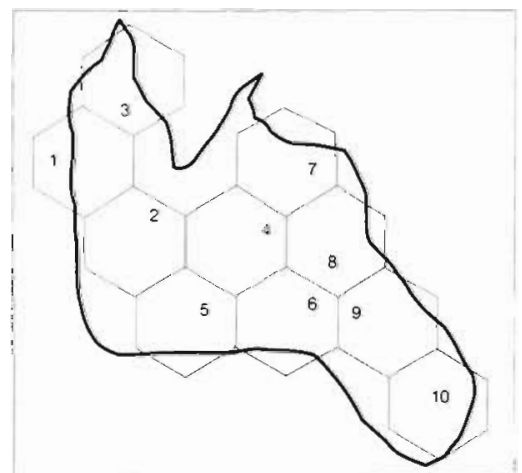

Fig. 2. Map of Rabbit Key Basin with hexagonal grid overlay. Numbers represent approximate sampling locations within each region. Bold line represents the boundary of the basin. Areas outside of this line are shallow mudbanks, areas inside average $5-6$ feet $(1.5-1.8 \mathrm{~m})$ in depth
Sample processing. The short shoots were scraped carefully to remove epiphytes and DNA was extracted from them using a nuclear extraction technique designed for plants that are high in phenolic compounds (Weising et al. 1995). This method involves first isolating the nuclei and then extracting DNA from them. We found that nuclear extraction was necessary due to the large amounts of phenolic compounds found in Thalassia testudinum, which caused contamination problems with standard DNA extraction techniques. When these phenolic compounds come into contact with the DNA, they render it unamplifiable. Only leaf tissue was used in the extraction procedure. All samples were stored at $-20^{\circ} \mathrm{C}$ in $1 \mathrm{X}$ TE Buffer $(0.01 \mathrm{M}$ Tris, $0.001 \mathrm{M}$ EDTA, $\mathrm{pH}$ 8.0) until use (up to $5 \mathrm{mo}$ ).

We used the inter simple sequence repeat (interSSR) DNA fingerprinting technique (Zietkiewicz et al. 1994). This method takes advantage of microsatellites, also known as simple sequence repeat (SSR) DNAs, which are a class of repetitive DNAs that occur frequently in most eucaryotic genomes (Tautz 1989, Weising et al. 1991, Hughes \& Queller 1993, Morgante \& Olivieri 1993). Use of a single complementary primer will cause amplification of the intervening region when 2 microsatellites occur within an amplifiable distance of each other and on opposite strands. We compared amplification products of 3 of the repeat sequences presented by Zietkiewicz et al. (1994) as well as 4 others (Table 1) between samples from Bermuda and samples collected in Florida and chose the 2 primers that identified the most variation for further use in this experiment (Primers 2 and 4). In order to test the utility of the inter-SSR technique, we first amplified a set of 10 samples (all samples from 1 of the collection locations), 4 times independently. To test for somatic variability we then amplified multiple samples that were collected from along the same rhizome.

The 2 primers used in this study were end-labeled using $\gamma^{32}$ P ATP (6000 $\mathrm{Ci} \mathrm{mmol}^{-1}$; NEN) and T4 polynucleotide kinase (New England Bio Labs) and used to screen the 100 potential individuals collected from our Rabbit Key Basin sites. All amplifications were performed in $25 \mu$ l volumes with 2 units Taq DNA polymerase (Promega), $1 \times$ Thermophilic Buffer (Promega, from $10 \times$ stock containing $500 \mathrm{mM} \mathrm{KCl}, 100 \mathrm{mM}$ Tris$\mathrm{HCl} \mathrm{pH} \mathrm{9.0,} \mathrm{and} 1 \%$ Triton X-100), $1.5 \mathrm{mM} \mathrm{MgCl}_{2}$, $0.6 \mu \mathrm{M}$ primer (synthesized by Life Technologies), $0.4 \mu \mathrm{M}$ radio-labeled primer, $2.0 \mathrm{nM}$ dNTP (Promega) and $50 \mathrm{ng}$ of template DNA. PCR reactions were performed in an MJ Research PTC-200 thermocycler with an initial denaturation of $3 \mathrm{~min}$ at $95^{\circ} \mathrm{C}$ followed by 30 cycles of $95^{\circ} \mathrm{C}$ for $30 \mathrm{~s}, 50^{\circ} \mathrm{C}$ for $30 \mathrm{~s}, 72^{\circ} \mathrm{C}$ for $1 \mathrm{~min}$, followed by a final extension step of $72^{\circ} \mathrm{C}$ for $10 \mathrm{~min}$. Amplification products were separated on $72 \mathrm{~cm} 5 \%$ polyacrylamide gels. Electrophoresis was carried out 
Table 1. Sequences of inter-SSR primers screened against Thalassia testudinum DNA. "Primers suggested by Zietkewicz et al. (1.994)

\begin{tabular}{|cl|}
\hline Primer no. & Sequence \\
\hline 1 & CACACACACACACACARY \\
2 & CACACACACACACACARG \\
3 & BDBCACACACACACACA \\
4 & GAGAGAGAGAGAGAGAHC \\
5 & BHBGAGAGAGAGAGAGA \\
6 & VHVCTCTCTCTCTCTCT \\
7 & GACA \\
\hline
\end{tabular}

at $10 \mathrm{~W}$ for $9 \mathrm{~h}$ in $1 \times \mathrm{TBE}(0.89 \mathrm{M}$ Tris- $\mathrm{HCl}, 0.89 \mathrm{M}$ boric acid, 2.0 mM EDTA, pH 8.0) on a Bio-Rad Sequi-Gen sequencing cell. The gels were dried and exposed to $\mathrm{x}$-ray film for a period of $24 \mathrm{~h}$ before the film was developed. All potential individuals were scored for presence/absence of polymorphic bands by assigning a 1 if the band was present and a 0 if it was absent. No questionable bands were scored. The string of ones and zeros that resulted from amplification with both primers was interpreted as the molecular phenotype of each individual.

Statistical analysis. We calculated pairwise genetic distances between all pairs of potential individuals using the distance metric suggested by Excoffier et al. (1992):

$$
\delta_{x y}^{2}=\sum_{i=1}^{S}\left(x_{i}-y_{i}\right)^{2}
$$

where $\delta_{x y}^{2}=$ the squared distance between potential individuals $x$ and $y_{1} x=$ the banding pattern of individual $x, y=$ the banding pattern of individual $y$, and $S=$ the total number of loci for which the individuals were scored. The values generated thus represented a count of the number of loci at which the 2 potential individuals differed. The genetic distance values were plotted against geographic distances between samples.

The phenotypic data were also analyzed using the analysis of molecular variance (AMOVA) technique to look for spatial structuring in the dataset (Excoffier et al. 1992). The AMOVA is an adaptation of the more common ANOVA for binary data and allows for inferences about population structure from a distance matrix of molecular phenotypes (Huff et al. 1993, Peakall et al. 1995, Stewart \& Excoffier 1996). We used the AMOVA program in a more qualitative way to analyze the dataset based on phenotypic variation without making any assumptions about genetic distances between individuals.

When used in this way, AMOVA is essentially an hierarchical ANOVA that determines the amount of variation within a dataset that occurs at each of 3 hierarchical levels: (1) variation among regions; (2) varia- tion among populations within regions; and (3) variation among individuals within populations. We defined a 'region' as a hexagonal sampling grid, a 'population' as our individual sample quadrats, and 'populations within regions' as our paired quadrats within each hexagonal region. Thus, variation apportioned to the 'within population' level meant that there were multiple phenotypes identified within a single quadrat

Using seagrass coverage maps from high resolution satellite images $(10$ to $30 \mathrm{~m})$ processed in ARCINFO, we were able to reconstruct the die-off history of Rabbit Key Basin (Florida Bay Monitoring Project, 1998). Data from ARCINFO were classified into 3 density categories: (1) dense coverage (>70\%); (2) moderate coverage $(20$ to $70 \%)$; and (3) sparse coverage $(<20 \%)$. Coverage maps were generated for each of the $4 \mathrm{yr}$ that satellite images were available: 1985, 1988, 1990, and 1994 and the 10 locations that we sampled within Rabbit Key Basin were identified on each of the coverages. Through the use of these coverage maps, we were able to determine which sampling sites had never been affected by die-off, which sites had been completely denuded of seagrass cover but since recolonized, and which sites died off but did not recover.

\section{RESULTS}

Even after the nuclear isolation procedure, we found that some samples could not be amplified. Of the 100 samples that we collected, 74 amplified consistently and thus were included in the final dataset. The nonamplifiable samples were randomly distributed among the different sampling regions. In comparing the banding patterns of multiple amplifications of the same 10 potential individuals, we found no among-run variability. Further, banding patterns of multiple shoots from the same rhizome showed no evidence of somatic mutation along a rhizome. These results suggested that inter-SSR is a repeatable and reliable method for differentiating genetic individuals of Thalassia testudinum.

Of the 20 total quadrats we sampled, only 2 were not represented in the final dataset. The primer $(\mathrm{GA})_{8} \mathrm{HC}$ produced 16 easily identifiable bands. Of these, 8 were found to be polymorphic across the dataset. None of these 8 polymorphic loci were detected in fewer than 2 different hexagonal regions. The second primer, (CA) ${ }_{8} R G$, identified 2 additional polymorphic loci (out of 9 total bands) in 46 of the 74 samples; the remaining 28 samples did not amplify with this primer. These 28 samples included all samples collected from Regions 1 , 2 and 4 , and thus the variation we present for these areas is slightly more conservative than that presented for samples from the other regions. 


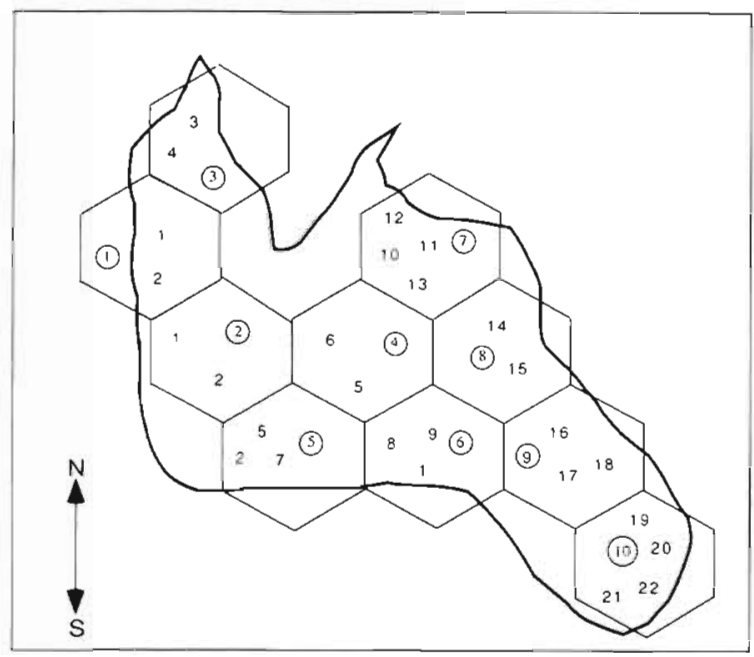

Fig. 3. Map of where molecular phenotypes were detected. Circled numbers indicate sampling regions and are placed at the approximate sampling point in each region. Plain numbers represent the molecular phenotypes found within each region. For a breakdown of phenotypes by quadrat see Table 2

Analysis of banding patterns yielded 22 unique multilocus fingerprints among the 74 possible individuals. Of the 22 phenotypes identified, $6(27 \%)$ were unique (detected only once). Because some individuals were detected multiple times and some only once, an understanding of the diversity in this dataset is dependent upon an understanding of the frequency with which each of these phenotypes occurs (Fig. 3, Table 2). All hexagonal regions were represented by at least 2 phenotypes. Additionally, in most cases, the paired quadrats within a region shared some of the same phenotypes. In all but 1 case, the same phenotype was identified in multiple samples from the same quadrat despite our attempts to collect separate rhizomes. Of the 18 quadrats represented, we did not detect variation in 3

Of the 22 phenotypes identified, 3 occurred in multiple hexagonal regions (Fig. 3). Of these, 2 (phenotypes 1 and 2) occurred in 3 regions and 1 (phenotype 5) occurred in 2 regions. When a phenotype occurred in more than 1 region, the regions in which it occurred were always adjacent to each other except in the case of phenotype Primer 1 which was found in Regions 1,2 and 6 . All 3 phenotypes that were detected in multiple hexagonal regions were among the samples that did not amplify with the second primer. Thus, it is likely that the detection of a phenotype in multiple regions may actually represent multiple closely related individuals that could not be distinguished with the low level of resolution used here. We feel that had these samples amplified with the second primer, they would represent multiple phenotypes.
Table 2. Phenoytpes identified in each quadrat. The phenotype labels were arbitrarily assigned

\begin{tabular}{|c|c|c|c|}
\hline Region & Quadrat & No. of potential & Phenotypes \\
\hline 1 & 2 & 4 & 1222 \\
\hline 2 & 1 & 5 & 12222 \\
\hline 2 & 2 & 5 & 22222 \\
\hline 3 & 1 & 5 & 33344 \\
\hline 3 & 2 & 5 & 33334 \\
\hline 4 & 1 & 3 & 555 \\
\hline 4 & 2 & 3 & 556 \\
\hline 5 & 1 & 5 & 22255 \\
\hline 5 & 2 & 4 & 2577 \\
\hline 6 & 1 & 3 & 888 \\
\hline 6 & 2 & 3 & 199 \\
\hline 7 & 1 & 5 & $\begin{array}{lllll}10 & 11 & 11 & 12 & 13\end{array}$ \\
\hline 7 & 2 & 5 & $\begin{array}{lllll}11 & 11 & 11 & 12 & 13\end{array}$ \\
\hline 8 & 4 & 4 & $14 \quad 14 \quad 14 \quad 15$ \\
\hline 9 & 1 & 2 & 1617 \\
\hline 9 & 2 & 5 & $\begin{array}{lllll}17 & 17 & 17 & 17 & 18\end{array}$ \\
\hline 10 & 1 & 2 & $1920 \quad 20 \quad 21$ \\
\hline 10 & 2 & 4 & $2020 \quad 20 \quad 22$ \\
\hline
\end{tabular}

AMOVA was also conducted on this dataset (Table 3 ). Bartlett's test did not refute the assumption of homogeneity of variance $(p<0.009)$. This analysis detected significant levels of variation at both the quadrat and hexagon levels ( $p<0.009$ in both cases) but very little of the variation was attributed to the paired quadrat level and this result was not significant ( $p=0.306)$. In the meadows sampled here, over half of the variation $(54 \%)$ occurred at the smallest spatial scale while a large percentage $(43 \%)$ also occurred at the largest spatial scale. These results indicate that multiple genetically distinct individuals occurred within the area of a single quadrat. Additionally, the large percentage of variation attributed to the largest spatial scale indicates that there is population structuring at this level. In other words, most phenotypes did not occur in multiple hexagonal regions.

To investigate genetic variation within these samples in a more quantitative way, we analyzed a matrix of pairwise genetic distances between all 22 phenotypes identified within Rabbit Key Basin (Table 4).

Table 3. Analysis of molecular variance results. Significant variation was detected at the hexagon and quadrat levels but not at the paired quadrat level

\begin{tabular}{|lrccr|}
\hline Source of variation & df & MS & of variation & \multicolumn{1}{c|}{$p$} \\
\hline Regions & 9 & 1.824 & 42.55 & $<0.0099$ \\
Quadrats within regions & 8 & 0.324 & 3.29 & 0.3069 \\
Quadrats & 56 & 0.260 & 54.17 & $<0.0099$ \\
\hline
\end{tabular}


Table 4. Genetic distances among the 22 molecular phenotypes identified in Rabbit Key Basin. Bold numbers represent phenotype labels

\begin{tabular}{|c|c|c|c|c|c|c|c|c|c|c|c|c|c|c|c|c|c|c|c|c|c|c|}
\hline & 1 & 2 & 3 & 4 & 5 & 6 & 7 & 8 & 9 & 10 & 11 & 12 & 13 & 14 & 15 & 16 & 17 & 18 & 19 & 20 & 21 & 22 \\
\hline 1 & 0 & & & & & & & & & & & & & & & & & & & & & \\
\hline 2 & 2 & 0 & & & & & & & & & & & & & & & & & & & & \\
\hline 3 & 5 & 3 & 0 & & & & & & & & & & & & & & & & & & & \\
\hline 4 & 4 & 2 & 1 & 0 & & & & & & & & & & & & & & & & & & \\
\hline 5 & 3 & 1 & 2 & 1 & 0 & & & & & & & & & & & & & & & & & \\
\hline 6 & 5 & 3 & 4 & 3 & 2 & 0 & & & & & & & & & & & & & & & & \\
\hline 7 & 2 & 2 & 3 & 2 & 1 & 2 & 0 & & & & & & & & & & & & & & & \\
\hline 8 & 1 & 1 & 4 & & 2 & 4 & 1 & 0 & & & & & & & & & & & & & & \\
\hline 9 & 1 & 3 & 4 & 5 & 4 & 6 & 3 & 2 & 0 & & & & & & & & & & & & & \\
\hline 10 & 7 & 5 & 2 & 3 & 4 & 6 & 5 & 6 & 6 & 0 & & & & & & & & & & & & \\
\hline 11 & 6 & 4 & 1 & 2 & 3 & 5 & 4 & 5 & 5 & 1 & 0 & & & & & & & & & & & \\
\hline 12 & 5 & 3 & 2 & 1 & 2 & 4 & 6 & 4 & 6 & 2 & 1 & 0 & & & & & & & & & & \\
\hline 13 & 6 & 4 & 3 & 2 & 3 & 5 & 4 & 5 & 7 & 1 & 2 & 1 & 0 & & & & & & & & & \\
\hline 14 & 7 & 5 & 6 & 5 & 4 & 2 & 5 & 6 & 8 & 5 & 5 & 4 & 5 & 0 & & & & & & & & \\
\hline 15 & 6 & 4 & 5 & 4 & 3 & 1 & 4 & 5 & 7 & 7 & 6 & 5 & 6 & 1 & 0 & & & & & & & \\
\hline 16 & 5 & 5 & 4 & 5 & 4 & 4 & 5 & 6 & 4 & 6 & 5 & 6 & 7 & 4 & 3 & 0 & & & & & & \\
\hline 17 & 3 & 5 & 6 & 5 & 4 & 4 & 3 & 4 & 4 & 8 & 7 & 6 & 7 & 4 & 3 & 2 & 0 & & & & & \\
\hline 18 & 4 & 6 & 7 & 6 & 5 & 5 & 4 & 5 & 5 & 7 & 8 & 7 & 6 & 5 & 4 & 3 & 1 & 0 & & & & \\
\hline 19 & 4 & 4 & 5 & 4 & 3 & 3 & 4 & 5 & 5 & 5 & 6 & 5 & 4 & 5 & 4 & 3 & 3 & 2 & 0 & & & \\
\hline 20 & 3 & 3 & 4 & 3 & 2 & 2 & 3 & 4 & 4 & 6 & 5 & 4 & 5 & 4 & 3 & 2 & 2 & 3 & 1 & 0 & & \\
\hline 21 & 5 & 3 & 4 & 3 & 2 & 2 & 3 & 4 & 6 & 4 & 5 & 4 & 3 & 4 & 3 & 4 & 4 & 3 & 1 & 2 & 0 & \\
\hline 22 & 4 & 4 & 5 & 4 & 3 & 1 & 4 & 5 & 5 & 7 & 6 & 5 & 6 & 3 & 2 & 3 & 3 & 4 & 2 & 1 & 3 & 0 \\
\hline
\end{tabular}

These genetic distances were plotted against the geographic distances between sampling points to test for evidence of a spatial relationship (Fig. 4). Field measurements of geographic distance were: (1) $25 \mathrm{~cm}$ as the within quadrat distance (we did not measure the actual distance between individual rhizomes within each quadrat and thus, for this analysis, we assigned a distance value of $25 \mathrm{~cm}$ to all samples at this level as that was the maximum possible separation): (2) the distance between the randomly thrown paired quadrats within each region (1.0 to $16.5 \mathrm{~m})$; and (3) distances between the general sampling points within each hexagonal region (based on calculation from GPS coordinates). The data plotted as 3 spatial clusters (Fig. 4). The genetic distance value plotted for each point was the greatest observed genetic distance between all combinations of phenotypes that occurred at the 2 points being compared. A linear regression detected a significant effect ( $p<0.001, r^{2}=0.602$ ) of geographic distance on mean genetic distances among individuals. Scheffe's multiple comparison test showed that genetic distance values at the hexagonal scale were significantly greater than genetic distances at the quadrat and paired quadrat scales. Thus, individuals that were separated by kilometers had a significantly greater genetic distance than individuals separated by less than $16.5 \mathrm{~m}$.

After square root transformation of the data to achieve homogeneity of variances, ANOVA detected significant differences in measured short shoot densities ( $p<0.001)$ between sampling locations (Table 5). Average density values ranged from 139 to 766 short shoots $\mathrm{m}^{-2}$. Average short shoot densities within the basin increased from west to east. These measured densities, which were recorded in 1997, corresponded reasonably well to the 1994 density values assigned to each location in the ARCINFO coverage map from that year (Table 6). Thus, there doesn't appear to have been any drastic change in seagrass cover within the areas that we sampled over the past 3 yr. An exception was Hexagon 10 which had the highest density score in our dataset yet received only a

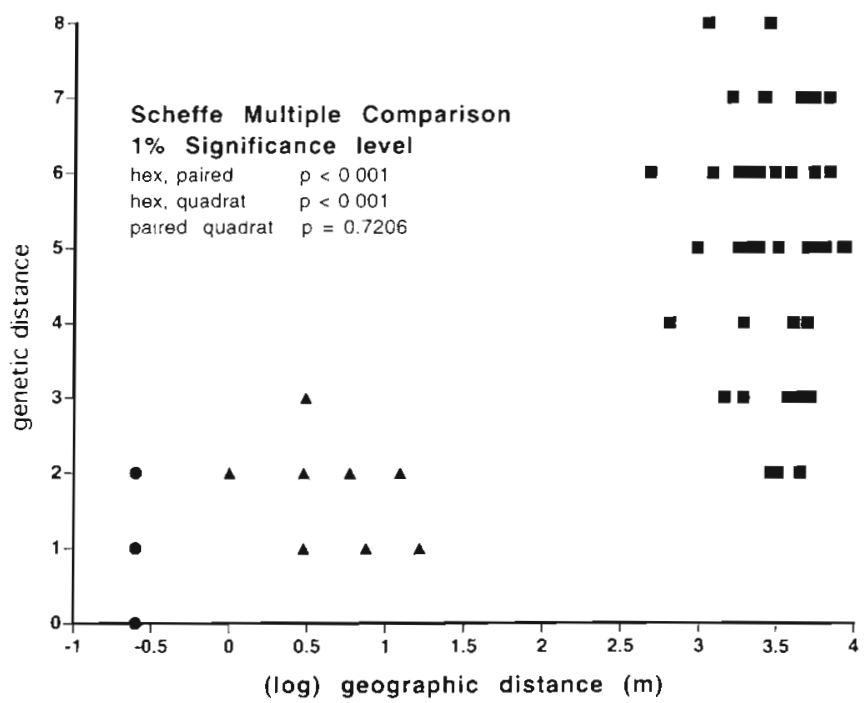

Fig. 4. Mean genetic versus geographic distance at 3 hierarchical scales: quadrats $(0)(0.25 \mathrm{~m})$; paired quadrats within regions (4) (1.0 to $16.5 \mathrm{~m}$ ); and hexagonal regions ( $\mathbf{- 1}$ (1 to $5 \mathrm{~km}$ ) 
Table 5. Nean short shoot densities counted within each hexagonal region. All counts were made in the summer of 1997. Densities were not counted in Region no. 9. ANOVA detected significant differences in short shoot density between sampling regions $(p<0.001)$

\begin{tabular}{|c|c|c|c|c|c|c|c|c|c|}
\hline Hexagon no. & 10 & 6 & 8 & 7 & 1 & 3 & 5 & 2 & 4 \\
\hline Mean density $\mathrm{m}^{-2}$ & 766 & 678 & 523 & 393 & 320 & 243 & 202 & 168 & 139 \\
\hline $\begin{array}{l}\text { Scheffe's } \\
\text { paired comparisons }\end{array}$ & & & & & & & & & \\
\hline
\end{tabular}

tionship was detected between average short shoot density and the number of phenotypes detected at each site $\left(\mathrm{r}^{2}=\right.$ $0.36, p=0.08)$, though the sample size was small.

\section{DISCUSSION}

Our results indicated that the Thalassia testudinum meadow in Rabbit Key Basin consists of multiple individuals or clones.

moderate (20 to $70 \%$ coverage) ranking in 1994 . This discreparcy suggests that Region 10 has continued to recover from die-off since 1994.

To test for a relationship between clonal diversity and known recent history of seagrass die-off, we related trends in seagrass coverage within Rabbit Key Basin to measured levels of clonal diversity. We first used Simpson's diversity index (Simpson 1949) to convert our molecular phenotype data into a measure that accounted for our uneven sample sizes (caused by the fact that some samples were not amplifiable) and to account for the proportional abundance of each phenotype we encountered. Thus, this value describes diversity in terms of the number of different phenotypes detected and in terms of the abundance of each phenotype in any given region. These data were then compared to the 4 historical seagrass coverage values determined for each site (Table 6). Sites 1 and 3 were excluded from this analysis because they did not fall within the area of the coverage maps. Sites 2 and 4 were also excluded because they did not amplify with the second primer and thus could not be compared directly with the rest. Among Regions 5 to 10, coverage histories and intensities of die-off were variable. There was no apparent trend in these data; however, the region that exhibited the most intense die-off (Region 10) had the greatest diversity value. Region 10 was also the site with the greatest measured short shoot density at the time of sampling. Notably, a weak positive rela-

Table 6 . Seagrass coverage values generated with ARC/INFO from high resolution satellite images. $\mathrm{S}=$ sparse $(<20 \%$ cover), $\mathrm{M}=$ moderate ( 20 to $70 \%$ cover) and $\mathrm{D}=$ dense $(>70 \%$ cover). Simpson's diversity values represent 1997-1998 clonal diversity levels within each of the sampling regions

\begin{tabular}{|cccccc|}
\hline Site & 1985 & 1988 & 1990 & 1994 & $\begin{array}{c}\text { Simpson's } \\
\text { diversity }\end{array}$ \\
\hline 5 & $\mathrm{M}$ & $\mathrm{M}$ & $\mathrm{M}$ & $\mathrm{M}$ & 2.00 \\
6 & $\mathrm{M}$ & $\mathrm{D}$ & $\mathrm{M}$ & $\mathrm{D}$ & 2.58 \\
7 & $\mathrm{D}$ & $\mathrm{D}$ & $\mathrm{M}$ & $\mathrm{M}$ & 2.62 \\
8 & $\mathrm{D}$ & $\mathrm{D}$ & $\mathrm{M}$ & $\mathrm{M}$ & 1.60 \\
9 & $\mathrm{D}$ & $\mathrm{M}$ & $\mathrm{D}$ & $\mathrm{D}$ & 1.81 \\
10 & $\mathrm{D}$ & $\mathrm{S}$ & $\mathrm{S}$ & $\mathrm{M}$ & 3.57 \\
\hline
\end{tabular}

A single primer detected 14 unique multi-locus phenotypes among 74 individuals. When 2 primers were used, the number of unique phenotypes increased to 22 . The fact that addition of a second primer resulted in a substantial increase in variability suggests that there are likely to be greater levels of variability within this population than we were able to show here. Thus, we feel confident that the minimal level of clonal diversity we observed is conservative for this area.

That this meadow is composed of multiple individuals is not surprising based on recent findings in Thalassia testudinum as well as for other seagrass species (Harrison \& Durance 1992, Alberte et al. 1994, Waycott 1995, Capiomont et al. 1996, Procaccini \& Mazzella 1996, Ruckelshaus 1996, Waycott et al. 1996, Waycott et al. 1997, Kirsten et al. 1998, Schlueter \& Guttman 1998). The spatial scale at which variation was detected, however, was somewhat unexpected. AMOVA apportioned almost half of the variability in the data at the smallest spatial scale $(<25 \mathrm{~cm}$.) (Table 3). This variability translated to 4 unique phenotypes out of 5 samples in 1 quadrat and at least 2 phenotypes in all but 3 of the 18 quadrats sampled (Table 2). These findings suggest that even at very small scales, T. testudinum in Rabbit Key Basin usually does not grow in monoclonal patches. Instead, individuals grow very closely intertwined with each other. AMOVA also apportioned much of the variability at the largest spatial scale, which is on the order of kilometers. The fact that samples from different hexagonal regions exhibited different molecular phenotypes suggests that clones are generally not larger than the area of our hexagonal sampling regions. A small and non-significant portion of the variability in the data was apportioned to the intermediate level, reflecting that phenotypes detected in one of the paired quadrats within a region were also commonly detected in the other nearby quadrat from that same region.

The significant positive relationship between genetic distance and geographic distance suggests a pattern of isolation by distance (Slatkin 1993). In simple terms this relationship means that individuals that are closer 
together in space are more likely to be genetically similar. This type of relationship is expected in individuals with limited dispersal abilities (Slatkin 1993). If a population is panmictic then there should be no such relationship because an individual would be just as likely to mate with a distant individual as with a proximal individual. Additionally, no such relationship would be expected if drift material in the form of seeds or rhizome fragments played a large role in population structure because these would be distributed randomly in space. In this analysis we found no significant differences in levels of genetic distance between individuals that were separated by less than $16.5 \mathrm{~m}$ (this was our greatest between quadrat distance). However, there was an obvious increase in genetic distance values that occurred somewhere between the 10 and $1000 \mathrm{~m}$ spatial scales (Fig. 4). While multiple genets occur over small spatial scales, they are closely related and, thus, Thalassia testudinum appears to exist in patches of 'families'. These results suggest a larger role of sexual production in structuring the local population than was previously believed. It appears from the data presented here that at least some seeds settle in the local meadow in which they are produced.

In a recent study of Thalassia testudinum diversity in the lower Florida Keys, Schlueter \& Guttman (1998) also found relatively high levels of diversity. Using allozyme electrophoresis, they detected evidence of high levels of gene flow within local populations of $T$. testudinum, and gene flow was found to decrease with distance. These results, like our own, suggest population structuring. In another recent survey of genetic diversity in Thalassia testudinum populations in Florida, Kirsten et al. (1998) detected higher than expected levels of variation using RAPD fingerprinting. Populations separated by only 2 to $3 \mathrm{~km}$ were found to be genetically distinguishable. These results agree with our finding of population structuring within the area of Rabbit Key Basin. Further, Kirsten et al. (1998) detected different clones at sampling sites separated by as little as $10 \mathrm{~m}$. Our study, however, is the first to detect variation in plants separated by less than $0.25 \mathrm{~m}$.

We expected that our comparisons between historical seagrass coverage and current clonal diversity levels might uncover a relationship between seagrass dieoff and population structure. In areas characterized by decreased coverage over the last decade, for example, we expected to observe a decrease in clonal diversity as specific clones died. On the other hand, we expected that drastic increases in coverage after a die-off event represented recolonization events, either by seeds or vegetative growth. For the most part we were not able to detect any trends in clonal diversity as sample sizes for this analysis were small. It is interesting, how- ever, to note that Region 10 had not only the highest short shoot density measured in the study (Table 5) but also the highest Simpson's diversity value (Table 6). Region 10 includes an area of Rabbit Key Basin with one of the largest and most severe die-off patches as of 1991. This 1 die-off patch encompassed approximately 63 hectares and, within it, the sediments were completely denuded of cover (Robblee et al. 1991). This is the only one of our sites which received a rating of $\mathrm{S}$ (sparse, $20 \%$ cover) at any time over the 9 yr period covered by the satellite images (Table 6). The fact that this site is now one of the most diverse, in terms of numbers of genetically distinct clones, suggests that sexual reproduction and seedlings must have played a role in recolonization.

As stated above, the levels of genetic diversity detected in this study are extremely conservative. We believe that an increased number of markers would reveal greater levels of diversity and, thus, the cases where the same genets are found in different hexagonal sampling regions in this study would probably not occur. The fact that, in all but 1 case, there was repetition of genotypes sampled within each quadrat (despite our efforts to collect rhizomes that were connected) and between paired quadrats within each region, is indicative of the growth pattern of these highly clonal plants. A single genet is capable, via rhizome branching and growth, of spanning an area on the order of $25 \mathrm{~cm}$ across (and in many cases on the order of $10 \mathrm{~m}$ ); however, genets generally do not appear to exist exclusive of other individuals in an area of this size. Thus, while these data show that sexual reproduction probably plays a much larger role in population structuring than was previously thought, we are not discounting the dominance of vegetative propagation.

Understanding population structure within seagrass meadows is crucial to understanding ecosystem-level fluctuations in these systems. This work was intended to be a preliminary step in describing the population structure of Thalassia testudinum in Florida Bay. Continued studies in this area combined with further advances in molecular technology will vastly increase our knowledge of population structure within clonal plant populations and facilitate predictions of population dynamics within these important primary producers.

Acknowledgements. We thank Dr Robbie Smith and Dr Sheila McKenna of the Bermuda Biological Research Station for collecting and sending us samples, Braxton Davis, Patty Mumford, Todd Taylor, Rob Daoust, and Steve Davis for field help, and Blanca Cortez and Chris Sinigalliano for technical assistance. This work was partially supported by a grant to D.L.C. From the South Florida Water Management District. 


\section{LITERATURE CITED}

Alberte RS, Suba GK, Procaccini G, Zimmerman RC, Fain SR (1994) Assessment of genetic diversity of seagrass populations using DNA fingerprinting: implications for population stability and management. Proc Natl Acad Sci 91: 1049-1053

Barrett SCH, Eckert CG, Husband BC (1993) Evolutionary processes in aquatic plant populations. Aquat Bot 44: 105-145

Capiomont A, Sandmeier M. Caye G, Meinesz A (1996) Enzyme polymorphism in Posidonia oceanica, a seagrass endemic to the Mediterranean. Aquat Bot 54:265-277

Carlson PR Jr, Yarbro LA, Barber TR (1994) Relationship of sediment sulfide to mortality of Thalassia testudinum in Florida Bay. Bull Mar Sci 54(3):733-746

Cook RE (1983) Clonal plant populations. Am Sci 71(3): $244-253$

Cox P (1993) Water-pollinated plants. Sci Am 269(4):68-74

Cox PA, Tomlinson PB (1988) Pollination ecology of the seagrass, Thalassia testudinum (Hydrocharitaceae) in St. Croix. Am J Bot 75(7):958-965

Den Hartog (1970) The seagrasses of the world. NorthHolland, London

Durako MJ, Kuss KM (1994) Effects of Labyrinthula infection on the photosynthetic capacity of Thalassia testudinum. Bull Mar Sci 54(3):727-732

Durako MJ, Moffler MD (1985) Observations on the reproductive ecology of Thalassia testudinum (Hydrocharitaceae). IIl. Spatial and temporal variations in reproductive patterns within a seagrass bed. Aquat Bot 22: 265-276

Durako MJ, Moffler MD (1987) Factors affecting the reproductive ecology of Thalassia testudinum (Hydrocharitaceae). Aquat Bot 27:79-95

Excoffier L, Smouse PE, Quattro JM (1992) Analysis of molecular variance inferred from metric distances among DNA. haplotypes: application to human mitochondrial DNA. restriction data. Genetics 131:479-491

Florida Bay Monitoring Project (1998) U.S.-Russian Joint Commission on Economic and Technological Cooperation, Environmental Working Group. Final Report, Cent Intellig Agency, Langley, VA

Frankovich TA, Zieman JC (1994) Total epiphyte and epiphytic carbonate production on Thalassia testudinum across Florida Bay. Bull Mar Sci 54(3):679-695

Grace JB (1993) The adaptive significance of clonal reproduction in angiosperms: an aquatic perspective. Aquat Bot 44:158-180

Hall MO, Bell SS (1993) Meiofauna on the seagrass Thalassia testudinum: population characteristics of harpacticoid copepods and associations with algal epiphytes. Mar Biol 116(1):137-146

Harrison PG, Durance C (1992) Variation in clonal structure in an eelgrass (Zostera marina) meadow on the pacific coast of Canada. Can J Bot 70:653-657

Haymes DS (1994) Random amplified polymorphic DNA's and microsatellites: what are they and can they tell us anything we don't already know? Ann Ent Soc Am 87(6): $717-722$

Huff DR, Peakall R, Smouse PE (1993) RA.PD variation within and among natural populations of outcrossing Buffalograss (Buchloë dactyloides (Nutt.) Engelm). Theor Appl Genet 86:927-934

Hughes CR, Queller DC (1993) Detection of highly polymorphic microsatellite loci in a species with little allozyme polymorphism. Mol Ecol 2:131-137
Iverson RL, Bittaker HF (1986) Seagrass distribution and abundance in eastern Gulf of Mexico coastal waters. Estuar Coast Shelf Sci 22:577-602

Kaehler S, Hughes RG (1992) The distributions and growth patterns of three epiphytic hydroids on the Caribbean seagrass Thalassia testudinum. Bull Mar Sci 51(3):329-336

Kirsten JH, Dawes CJ, Cochrane BJ (1998) Randomly amplified polymorphism detection (RAPD) reveals high genetic diversity in Thalassia testudinum banks ex König (Turtlegrass\}. Aquat Bot 61:269-287

Koch EW (1996) Hydrodynamics of a shallow Thalassia testudinum bed in Florida, USA. In: Kuo J, Phillip RC, Walke DI, Kirkman H (eds) Seagrass biology: proceedings of an international workshop. Academic Press, New York, p $105-110$

Laushman RH (1993) Population genetics of hydrophilous angiosperms. Aquat Bot 44:147-158

Leber KM (1985) The influences of predatory decapods, refuge and microhabitat selection on seagrass communities. Ecology 66(6):1951-1964

Lewis FG III (1987) Crustacean epifauna of seagrass and macroalgae in Apalachee Bay, Florida, USA. Mar Biol 94(2):219-229

McMillan C (1980) Isozymes of tropical seagrasses from the Indopacific and the Gulf of Mexico-Caribbean. Aquat Bot $8: 163-172$

McMillan C (1982) Isozymes in seagrasses. Aquat Bot 14(3): $231-243$

Morgante M, Olivieri AM (1993) PCR-amplified microsatellites as markers in plant genetics. Plant $J$ 3(1):175-182

Murphey PL, Fonseca MS (1995) Role of high and low energy seagrass beds as nursery areas for Penaeus duorarum in North Carolina. Mar Ecol Prog Ser 121:91-98

Orpurt PA, Boral LL (1964) The flowers, fruits, and seeds of Thalassia testudinum Konig. Bull Mar Sci Gulf Caribb $14(2): 296-302$

Parker PG, Snow AA, Schug MD, Booton GC, Forest PA (1998) What molecules can tell us about populations choosing and using a molecular marker. Ecology 79(2) $361-382$

Peakall R, Smouse PE, Huff DR (1995) Evolutionary implications of allozyme and RAPD variation in diploid populations of dioecious buffalograss Buchloe dactyloides. Mol Ecol 4:135-147

Procaccini G, Mazzella L (1996) Genetic variability and reproduction in two Mediterranean seagrasses. In: Kuo J, Phillip RC, Walker DI, Kirkman H (eds) Seagrass biology: proceedings of an international workshop. Academic Press, New York, p 85-92

Robblee MB, Barber TR, Carlson PR Jr, Durako MJ, Fourqu rean JW, Muehlstein LK, Porter D, Yarbro LA, Zieman RT, Zieman JC (1991) Mass mortality of the tropical seagrass Thalassia testudinum in Florida Bay (USA). Mar Ecol Prog Ser 71:297-299

Ruckelshaus MH (1996) Estimation of genetic neighborhood parameters from pollen and seed dispersal in the marine angiosperm Zostera marina. Evolution 50(2):856-864

Schlueter MA, Guttman SI (1998) Gene flow and genetic diversity of turtle grass, Thalassia testudinum, Banks ex König, in the lower Florida Keys. Aquat Bot 61:147-164

Sculthorpe CD (1967) The biology of aquatic vascular plants. Edward Arnold, London

Simpson EH (1949) Measurement of diversity. Nature 163:688

Slatkin M (1993) Isolation by distance in equilibrium and nonequilibrium populations. Evolution 47(1):264-279

Stevens DL Jr (1994) Implementation of a national monitoring program. J Environ Manag 42:1-29 
Stewart CN Jr, Excoffier L (1996) Assessing population genetic structure and variability with RAPD data: application to Vaccinium macrocarpon (American Cranberry). J Evol Biol 9:153-171

Stoner AW, Lewis FG III (1985) The influence of quantitative and qualitative aspects of habitat complexity in tropical sea-grass meadows. J Exp Mar Biol Ecol 94:19-40

Tautz D (1989) Hypervariability of simple sequences as a general source for polymorphic DNA markers. Nucleic Acids Res 17(16):6463-6471

Tomasko DA, LaPointe BE (1994) An alternative hypothesis for the Florida Bay die-off. Bull Mar Sci 54(3):1086

Tomlinson PB (1969) On the morphology and anatomy of turtle grass, Thalassia testudinum (Hydrocharitaceae). III. Floral morphology and anatomy. Bull Mar Sci 19(2): 286-305

Tomlinson PB (1974) Vegetative morphology and meristem dependence - the foundation of productivity in seagrasses. Aquaculture 4:107-130

van Tussenbroek BI (1994) Aspects of the reproductive ecology of Thalassia testudinum in Puerto Morelos reef lagoon, Mexico. Bot Mar 37:413-419

Waycott M (1995) Assessment of genetic variation and clonality in the seagrass Posidonia australis using RAPD and allozyme analysis. Mar Ecol Prog Ser 116:289-295

Waycott M. Walker DI, James SH (1996) Genetic uniformity

Editorial responsibility: Kenneth Heck Jr (Contributing Editor), Dauphin Island, Alabama, USA in Amphibolis antarctica, a dioecious seagrass. Heredity 76:578-585

Waycott M, James SH, Walker DI (1997) Genetic variation within and between populations of Posidonia australis, a hydrophilous, clonal seagrass. Heredity 79:408-417

Weising K, Beyermann B, Ramser J, Kahl G (1991) Plant DNA fingerprinting with radioactive and dioxygenated oligo. nucleotide probes complementary to simple repetitive DNA sequences. Electrophoresis 12:159-169

Weising $K$, Nyborn $H$, Wolff $K$, Meyer W (1995) DNA tingerprinting in plants and fungi. CRC Press, Boca Raton

Williams SL, Adey WH (1983) Thalassia testudinum Banks ex König seedling success in a coral reef microcosm. Aquat Bot 16:181-188

Witz MJA, Dawes CJ (1995) Flowering and short shoot age in the three Thalassia testudinum meadows off west-central Florida. Bot Mar 38:431-436

Zieman JC, Fourqurean JW, Iverson RL (1989) Distribution, abundance and productivity of seagrasses and macroalgae in Florida Bay. Bull Mar Sci 44(1):292-311

Zieman JC, Davis R, Fourqurean JW, Robblee MB (1994] The role of climate in the Florida Bay seagrass die-off. Bull Mar Sci 54(3): 1088

Zietkiewicz E, Rafalski A, Labuda D (1994) Genome fingerprinting by simple sequence repeat (ssr)-anchored polymerase chain reaction amplification. Genomics 20:176-183

Submitted: September 15, 1998, Accepted: March 26, 1999 Proofs received from author(s): September 1, 1999 